\title{
AVALIAÇÃO DO USO E OCUPAÇÃO DO SOLO NAS BACIAS HIDROGRÁFICAS DO PIRAPÓ, PARANAPANEMA III E IV ${ }^{1}$
}

\author{
Amália Maria Goldberg Godoy ${ }^{2}$
}

\section{Maria Luzia Lomba de Sousa ${ }^{3}$}

\begin{abstract}
RESUMO: A ocupação humana na bacia hidrográfica do Paranapanema 4,Paranapanema 3 e Pirapó é demonstrada através das atividades econômicos desenvolvidas nos municípios que fazem parte das Bacias, sendo 56 no total. O presente artigo visa qualificar das diversas práticas agrícolas desenvolvidas, uso e ocupação do solo na bacia. Na presente pesquisa, buscou-se uma abordagem teórica que contemple o inter-relacionamento das variáveis ambientais, procurando caracterizar os relacionamentos entre os elementos naturais do meio e a dinâmica de uso e ocupação do solo atual. É iminente o risco, pois a atividade agrícola na bacia, o uso intensivo dos solos, o uso de agroquímicos, a urbanização, o uso da água para abastecimento público e irrigação, gerando assim impactos ambientais tanto em termos de erosão quanto em riscos de contaminação dos recursos hídricos.
\end{abstract}

Palavras-chave: Bacia hidrográfica; uso e ocupação do solo; agricultura; atividades econômicas.

\section{INTRODUÇÃO}

Este trabalho propõe investigar o uso e ocupação do solo, as práticas agrícolas desenvolvidas pela agricultura na bacia hidrográfica do Paranapanema 3, Paranapanema 4 e Pirapó. localizadas no Estado do Paraná, que ocupa uma área de aproximadamente 200.000 km²,

\footnotetext{
1 1.Artigo referente à Tese de Doutorado em andamento cujo título é "Desenvolvimento Econômico e Políticas Públicas para as Bacias Hidrográficas do Pirapó e Paranapanema III e IV".

${ }^{2}$ Prof $^{a}$ Dr$^{a}$ Departamento de Pós Graduação em Economia na UEM - Universidade Estadual de Maringá ${ }^{3}$ Doutoranda em Economia. Universidade Estadual de Maringá -UEM, Maringá-PR
} 
subdividido em 399 municípios, sendo 2,3\% do território brasileiro, compondo a região sul As Bacias Hidrográficas do Pirapó, Paranapanema III e IV localizadas na porção norte do Estado do Paraná, abrange 56 municípios dos 399 do Estado do Paraná.

Os aspectos que devem ser considerados para o estudo e dos problemas regionais são: evolução da ocupação do espaço regional, características atuais desse espaço e a dinâmica econômica da região nos períodos mais recentes, estabelecendo uma visão dinâmica regional.

Compreender a atividade econômica dos municípios das Bacias do Pirapó, Paranapanema III e IV inserida no espaço que é composto por 56 municípios paranaenses, constitui este estudo, juntamente com as Políticas Publicas e gestão ambiental da bacia hidrográfica em questão.

A gestão ambiental depende do desempenho das instituições e organizações que atuam no processo, desempenho esse que decorre da forma como estão organizadas, encontrando alternativas mais apropriadas a cada conjuntura.

\section{REVISÃO DA LITERATURA}

A Comissão Mundial de Meio Ambiente e Desenvolvimento definiu desenvolvimento sustentável como "[...] aquele que atende às necessidades do presente sem comprometer as possibilidades das gerações futuras atenderem suas próprias necessidades". Espinosa (1993) completa o conceito, afirma o Desenvolvimento sustentável procura incorporar a conservação ambiental, ao crescimento econômico e a eqüidade social.

O desenvolvimento regional pode ser pensado como extensão e incrementos de arranjos institucionais no território, tais como novos atores, novas esferas de intervenção, novas ações, fundamentos e processos metodológicos como inferência ou apoio. Na própria intenção que os caracteriza, sua implementação não é em si o desenvolvimento, mas um fator impulsionador. Segundo Almeida (1996) contribui para o Desenvolvimento regional elementos endógenos e forças passíveis de emergir ao gerar novas conexões e caminhos, com bases locais (ALMEIDA, 1996).

O desenvolvimento sustentável nas Bacias pode ocorrer através de ações cidadãs e os projetos focados no fomento dos movimentos ambientais e socioambientais, as inovações da gestão municipal e as tentativas de articulação de macroprogramas governamentais

Clemente e Higachi (2000, p. 14) define desenvolvimento regional como a delimitação de um espaço de planejamento. 
Esse conceito de espaço como conteúdo de um plano dá origem ao de região de planejamento. Uma empresa, ou órgão público, ou qualquer outro agente econômico possui sua região de planejamento, que influencia suas decisões e é afetada por estas. (...) Os planos de desenvolvimento regional constituem o exemplo típico de delimitação de região de planejamento pelo setor público.

O desenvolvimento acontece no território, com seus recursos e arranjos institucionais, como base para a construção do espaço produtivo, a cooperação se transforma em força produtiva, valendo-se da dinâmica das novas interações. O compartilhamento de saberes e a aprendizagem, o uso socializado de meios técnicos e informais, novas combinações de competição, a cooperação são fatores criam bases para novas dependência recíproca (AlYAR, 1996).

Portanto considerar a mudança no padrão de planejamento público como um sinal de mudança dos atores e da forma institucional de regular as ações estratégicas promove ambientes inovadores que se relacionam com uma nova institucionalidade nas esfera pública não estatal, que inicia de baixo com os agentes e agências governamentais.

O desenvolvimento regional permite associar programas públicos como foco na realidade local, de modo a recria-los e rearticulá-los com iniciativas originárias de novos arranjos institucionais, como por exemplo, os fóruns, comitês, consórcios e conselhos de desenvolvimento, que se estabeleçam com autonomia e legitimidade.

O desenvolvimento necessita uma nova formato de gestão pública onde o poder governamental local e diferentes atores desempenham o papel de autores e articuladores das políticas públicas, desde o planejamento, até a implantação e acompanhamento das ações destacando: a proteção e preservação do meio ambiente; a preservação e uso sustentável dos recursos hídricos; a coleta, o tratamento e a destinação correta do lixo; saneamento básico; recomposição e preservação da mata ciliar; entre outras que requerem ações articuladas.

Portanto não é possível em desenvolvimento sem pensar na preservação de um rio, sem pensar em suas bacias hidrográficas, seu entorno e nos municípios abrangidos por ela e segundo Farias (2002, p.103) o desenvolvimento leva em consideração a dimensão humana e social, redução da pobreza e fortalecimento da cidadania“[...] a abordagem tecnicista do tema do desenvolvimento deixa de ser hegemônica"

\section{PROCEDIMENTOS METODOLÓGICOS}




\section{anders \\ ISSN 1980-0827

Os procedimentos metodológicos foram quanto aos fins, a pesquisa é de natureza exploratória. A investigação exploratória é realizada em área na qual ha pouco conhecimento acumulado e sistematizado. Por sua natureza de sondagem, não comporta hipóteses tratando-se de aprofundar conceitos preliminares. Quanto aos meios utilizados, a pesquisa baseou-se em dados e informações bibliográficas e documentais. em órgãos públicos, anais, balancetes, fotografias, comunicações informais e outros.

As informações são sobre trabalhos já realizados, a literatura acerca das Bacias Hidrográficas, documentos do IBGE, Governo Estadual e Municipal, com a finalidade de construir um conhecimento teórico analítico que auxiliou no estabelecimento das variáveis, na elaboração da pesquisa. Portanto esta pesquisa teve caráter descritivo com abordagem de valores e índices.

\section{RESULTADOS E DISCUSSÃO}

A Bacia Hidrográfica do Pirapó esta localizada no terceiro planalto paranaense e nasce no município de Apucarana a 1.000 metros de altitude com área de $5.067 \mathrm{Km}^{2}$ de drenagem.. A Bacia do Paranapanema III possui uma área total de $3.776 \mathrm{Km}^{2} \mathrm{O}$ Paranapanema IV localiza-se a oeste da Bacia do Pirapó com $4.183 \mathrm{Km}^{2}$

De acordo com IPARDES (2012) a altitude das três Bacias varia de 300 m, em Ângulo, a 820m em Apucanara, constituídos por 56 municípios, ocupando 20.193,23Km².

A população total das três bacias é de 1.362.109 habitantes (IBGE, 2010), sendo que estavam $87.134(6 \%)$ no setor rural e 1.272 .975 (94\%), no setor urbano com relação ás bacias, a do Pirapó, possui 956.806 (70,2\% da população total das bacias), sendo 909.776 (95\% da bacia do Pirapó) estão no setor urbano e 47.030 (5\% da bacia) estão no setor rural. Ainda com relação a população da bacia, 535.695 pessoas que fazem parte da PEA (52,7\% do total), 512.023 estão ocupadas $(95,6 \%$ da PEA). 
Figura 1: População urbana, rural, Economicamente Ativa e Ocupada das Bacias

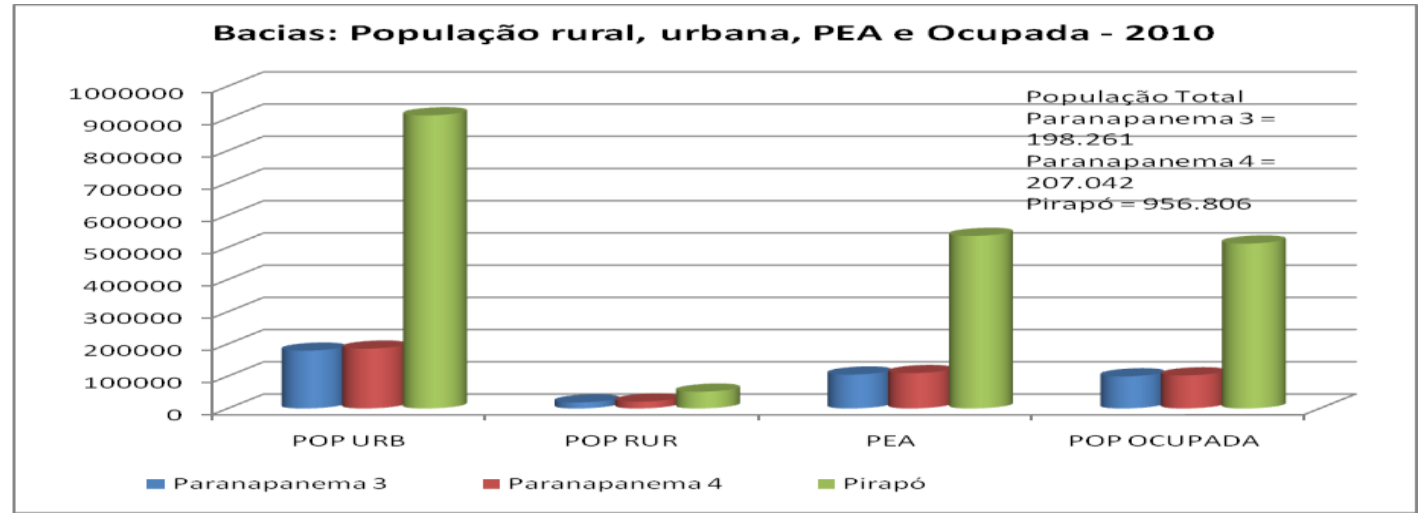

Fonte: http://www.ipardes.pr.gov.br/anuario_2010/index.html (2012)

Na Bacia do Paranapanema IV estão 207.042 hab. (15\% da população total das Bacias), dos quais 185.817 hab. (90\% da bacia) se situam no urbano e 21.225 (10\%) no rural. Da população total, fazem parte da PEA, 109.843 habitantes (47,1\%) e, destes, 102.869 estão ocupados (93,7\%).

Quanto ao Paranapanema III, sua população é de 198.261 hab.(15\% das Bacias) sendo 179.382 (90\%) de população urbana e 18.878 (10\%) de população rural. Da população total, 105.273 estão na PEA (49,7\%) e 99.752 estão ocupados (94,75\%).

Portanto, chama a atenção as PEAs - População Economicamente Ativa serem abaixo de $50 \%$, o que significa que ha um elevado numero de crianças e idosos nessas bacias. Mesma situação é a do Pirapó se bem que abaixo dos $60 \%$ a $65 \%$ considerados como normal.

\subsection{ASPECTOS GERAIS DAS BACIAS.}

O PIB - Produto Interno Bruto - que é o somatório dos valores gerados dentro de cada município. Se considerarmos as 3 bacias apresentados na Figura 5, o PIB total é de $R \$ 7.550 .904,61$ mil, dos quais $65 \%$ se originam da bacia do Pirapó ( $R \$ 4.930 .490,75)$, o Paranapanema III gera $27,2 \%$ ( $R \$ 2.059 .295,51)$ e o Paranapanema IV com $7,4 \%(R \$ 561.118,35)$. Além disso, é visível a participação da área de serviços em todas as bacias e, pela característica, pela concentração na bacia do Pirapó. Não se pode deixar de mencionar que o PIB Serviços engloba tanto a área de Serviços como o Comercio. Chama a atenção que no Paranapanema IV, a participação da agricultura no seu PIB é de 52,03\%. 
A bacia do Pirapó se destaca nos aspectos econômicos das bacias por ter a cidade-pólo de Maringá, que concentra de maneira acentuada a riqueza gerada e se destaca na Bacia e perante as demais bacias.

Figura 2: O PIB por setor na Bacia Hidrográfica- em $\mathrm{R} \$ 1.000,00$

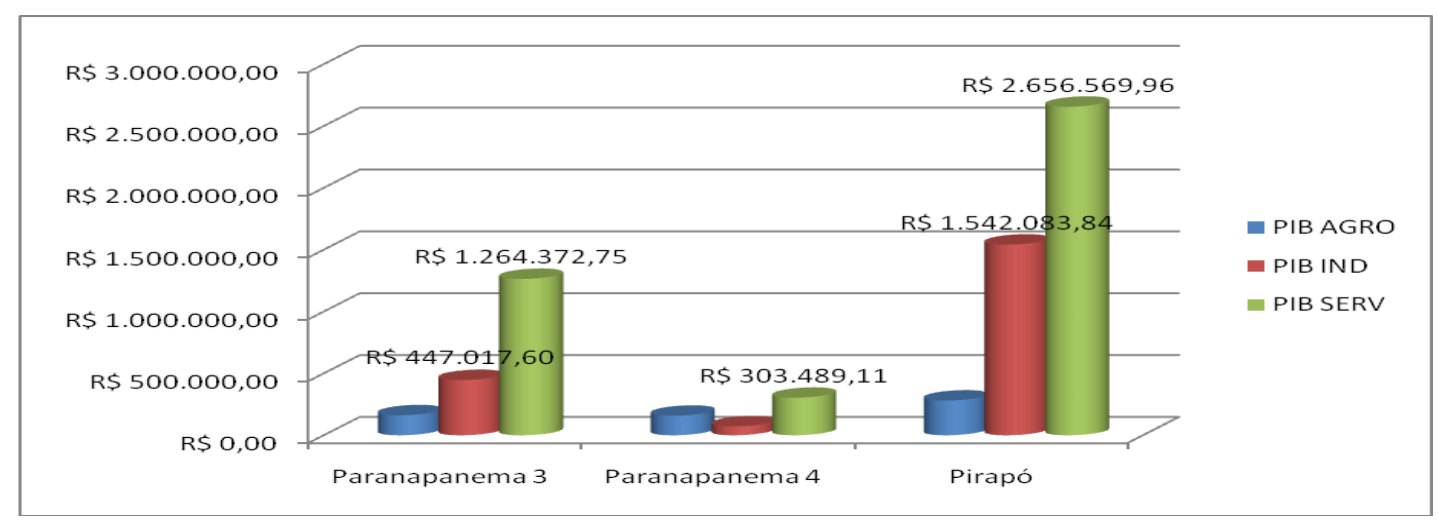

Fonte: http://www.ipardes.pr.gov.br/anuario_2010/index.html (2012)

Nas bacias concentram 6.409 indústrias que geram na média $R \$ 321,69$ mil no ano de 2010, que esta altamente concentrada no Pirapó.

Novamente, o Pirapó se destaca na quantidade de indústrias frente às demais bacias, ou seja, em 2010, possuía 5.140 indústrias formalizadas (80,2\% do total), das 6.409 existentes na bacia. Em relação o PIB,o Pirapó gera $R \$ 4.930 .490,75$ mil dos $R \$ 7.550 .904,61$, ou seja, a alta participação de 65,3\% da riqueza gerada na bacia Contudo, ao se dividir o PIB gerado pelas mesmas pelo número de indústrias, a situação se revela interessante, na medida em que no Paranapanema III encontra-se, na média um valor maior ( $\mathrm{R} \$ 792,58$ mil) do que o gerado no Pirapó ( $R \$ 300,01)$. Essa situação indica por um lado, a concentração de usinas e cooperativas nas regiões que geram grandes valores em poucas empresas, como no Paranapanema III. Por outro lado na Bacia do Pirapó, as empresas estão mais pulverizadas e diversificadas em vários ramos de atividades. 
Figura 3:Numero de Estabelecimentos por tamanho.

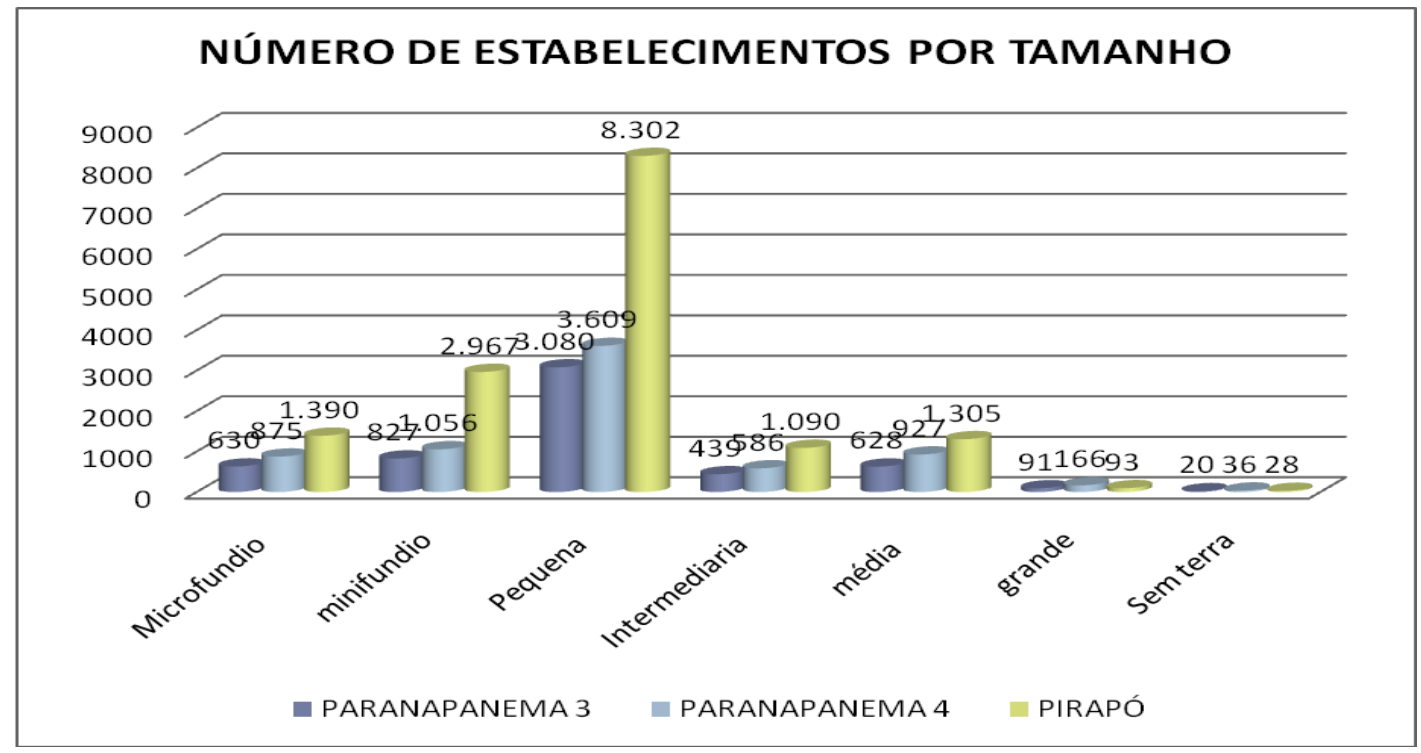

Fonte: http://www.ipardes.pr.gov.br/anuario_2010/index.html (2012)

Outro aspecto a ser abordado é o número de estabelecimentos agrícolas existentes nas bacias. Eles totalizam 28.147 estabelecimentos, dos quais $15.176(53,9 \%)$ estão localizados na bacia do Pirapó; na bacia do Paranapanema IV se localizam 7.256 estabelecimentos (25,8\% do total das bacias) e o Paranapanema III possui 5.715 estabelecimentos (20,3\%). Estes estabelecimentos possuem seus tamanhos conforme a Figura 3

Como observa-se, dos 28.147 estabelecimentos 7.745 são micro e minifúndios e 14.991 são pequenos, ou seja, nessas categoria estão 22.736 estabelecimentos ( $80,8 \%$ do total). Existem 2.800 estabelecimentos $(10,2 \%$ do total) são classificados como grande.

Outro aspecto importante na área rural é a condição do produtor, área e o número de estabelecimentos. Para isso, elaboram-se as figuras 4 e 5 . 


\section{Periódice Eletrânica \\ ISSN 1980-0827 \\ Fórum Ambiental \\ da Alta Paulista \\ Volume 8, Número 2, 2012 \\ Bacias Hidrográficas, Planejamento e \\ Gestão dos Recursos Hidricos}

ANAP

Figura 4: Estabelecimentos por condição de produtor.

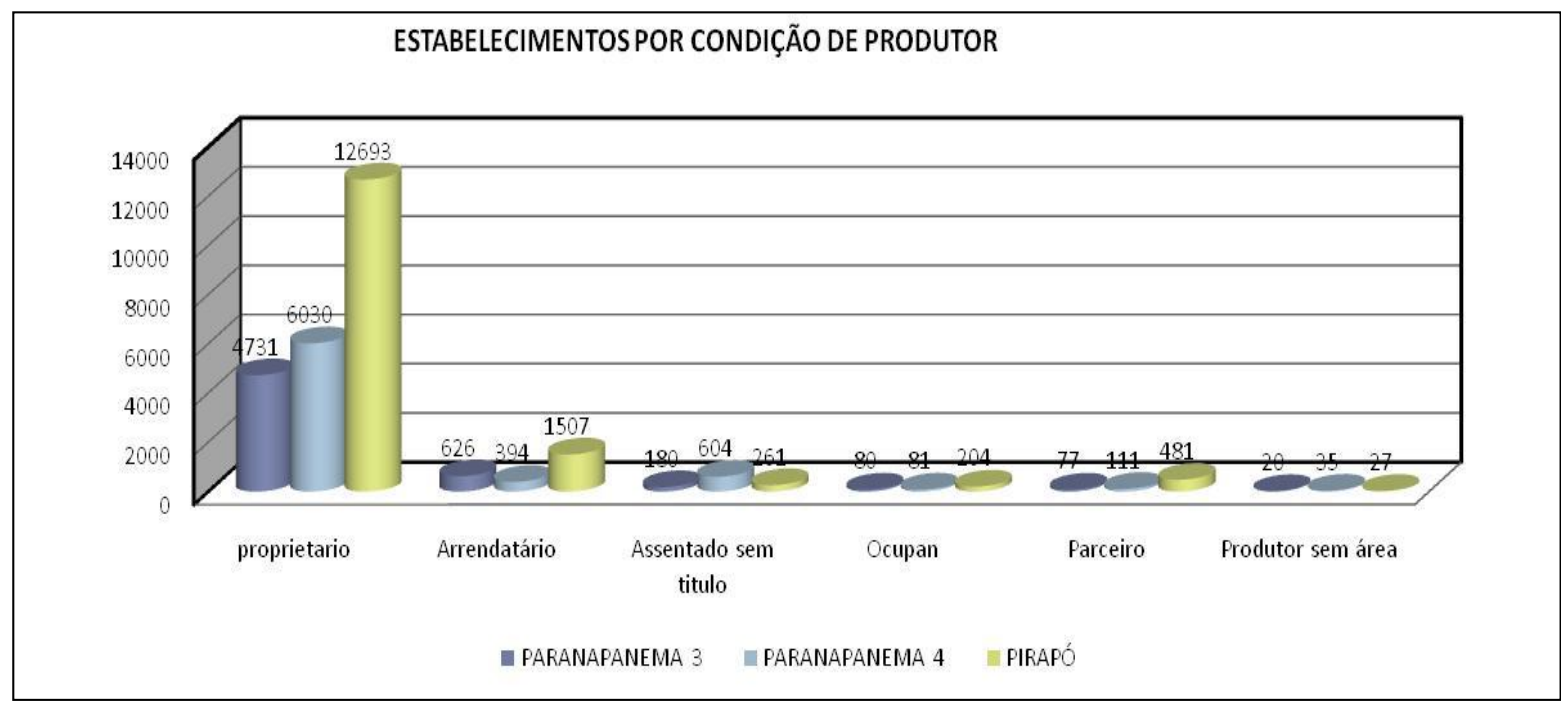

Fonte: http://www.ipardes.pr.gov.br/anuario_2010/index.html (2012)

Como se observa, grande parte dos estabelecimentos estão nas mãos dos proprietários, nas 3 bacias. A bacia do Pirapó se destaca pelo número de proprietários e arrendatários (tamanho em número e área ocupada) enquanto que no Paranapanema III existe maior número de assentados (embora em todas as bacias, eles estão presentes). O que chama a atenção são os parceiros no Paranapanema IV, enquanto que no Pirapó existem 481 estabelecimentos que ocupam uma área de 11.149 ha.(23,18 ha/estabelecimentos), no Paranapanema IV, apenas 111 estabelecimentos ocupam 9.406 ha.(84,73 ha/estabelecimentos) apontando para características diferentes das parceiras em grande parte na areada cana-de-açúcar e pecuária. A figura 8 apresenta a área e o número de estabelecimentos ocupadas pelas atividades agropecuárias das 3 bacia. 


\section{ace

Figura 5: Bacia: Quantidade e área da produção agropecuária.

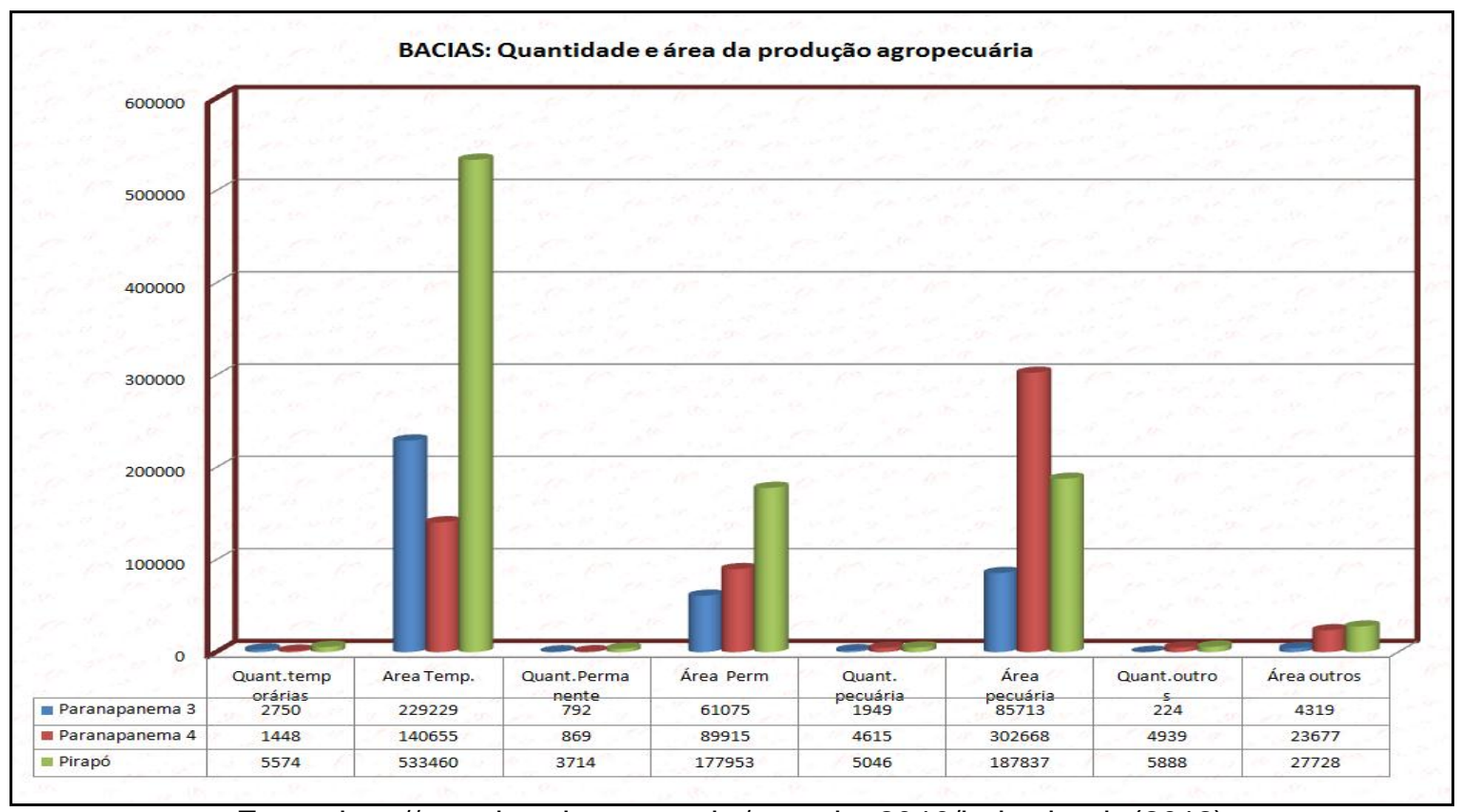

Fonte: http://www.ipardes.pr.gov.br/anuario 2010/index.html (2012)

Pela mesma percebe-se que o Pirapó se destaca, em magnitude, em todas as áreas de culturas e criação. Para as demais bacias, em área ocupada, tem-se que o Paranapanema III se destaca em culturas temporárias enquanto que o Paranapanema na Pecuária. Outro aspecto é a pequena área, relativamente ao total, ocupada com outras culturas, contudo com características diferenciadas: no Paranapanema IV (4.79 ha em media) e Pirapó (4,71 ha em media) enquanto no Paranapanema III se encontram em pequenas propriedades com na média 19,28 ha.

Todos os municípios possuem estabelecimentos com irrigação. Paranapanema III possui $3 \%$ dos estabelecimentos, dos quais se destacam Cambé com 49 estabelecimentos justificando maior PIB agrícola e alta produtividade das culturas de Soja , Trigo e Milho respectivamente. Bela Vista do Paraíso com 28 estabelecimentos e Primeiro de Maio com 23 estabelecimentos. No Paranapanema IV tem-se 2,8\% dos estabelecimentos com irrigação, destacando-se: Cruzeiro do Sul com 60 estabelecimentos, Paranavaí com 48 estabelecimentos. 


\section{rec

Figura 6: Número e percentual do total de estabelecimentos agropecuários com uso de irrigação em cada Bacia - 2010

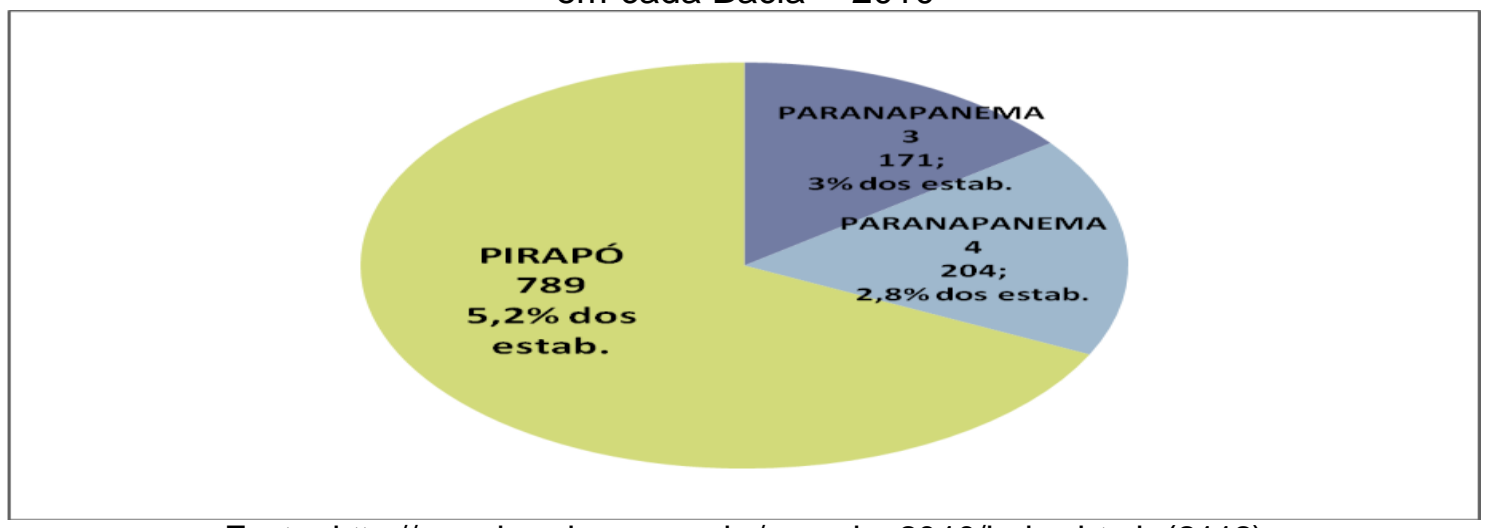

Fonte: http://www.ipardes.pr.gov.br/anuario 2010/index.html (2112)

Por último, a bacia do Pirapó possui 5,2\% dos municípios destacando-se: Apucarana com 89 estabelecimentos, Astorga com 40 estabelecimentos, Marialva com 221 estabelecimentos, Maringá com 94 estabelecimentos e Colorado com 36 estabelecimentos (Figura 6).

Cabe destacar que a irrigação contribuiu para valor do PIB agrícola e alta produtividade das culturas de Soja, Trigo e Milho respectivamente.

\section{2 CARACTERISTICAS GERAIS DE CADA BACIA}

\subsubsection{A Bacia Do Rio Paranapanema III}

$\mathrm{Na}$ Figura 7, distribuição do PIB por categorias Município, pode-se verificar que em Cambé se destaca muito perante as demais, particularmente, o de origem Serviços. e Industriais. Os Municípios, Bela Vista do Paraíso, Alvorada do Sul, Porecatu e Primeiro de Maio também se destacam em serviços. Cafeara e Nossa Senhora das Graças tem maior riqueza gerada na Agropecuária. A área industrial se identifica com a agroindústria. 
Figura 7: Paranapanema III- PIB por categoria Econômica dos Município em R $\$ 1.000,00$

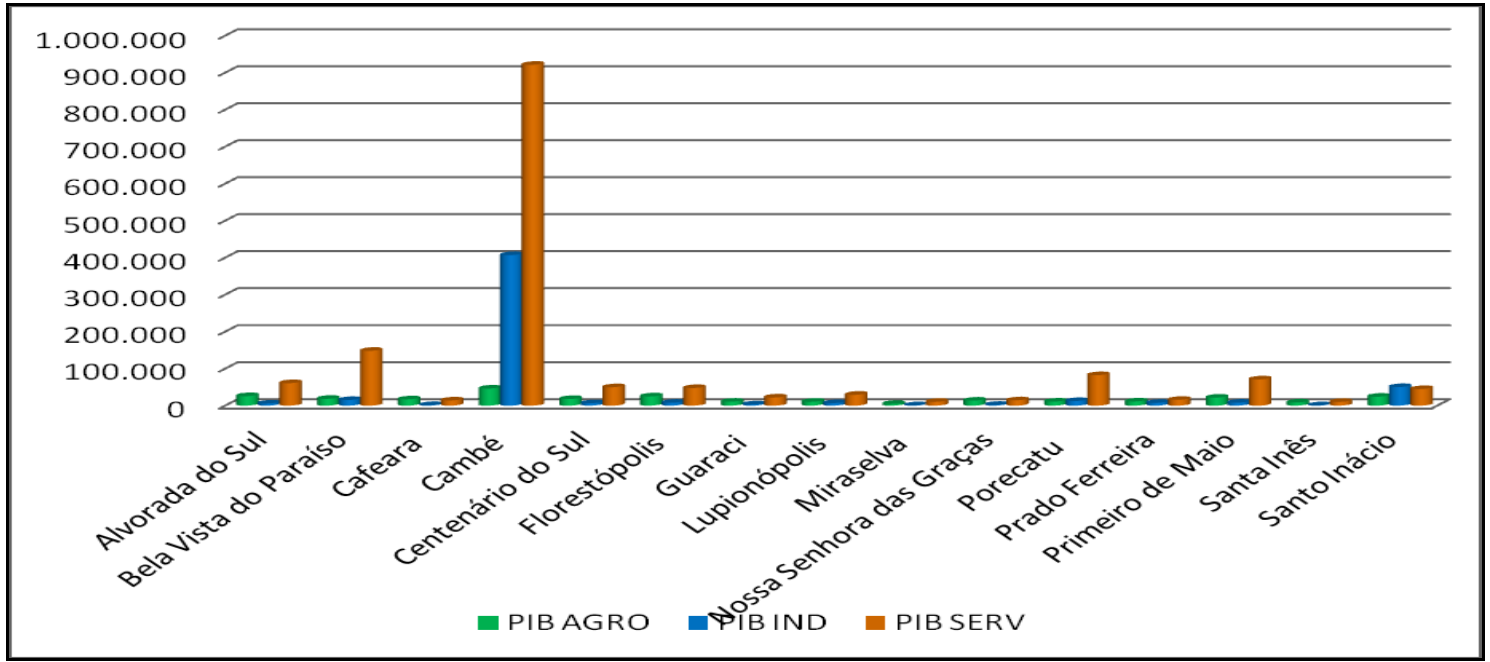

Fonte: http://www.ipardes.pr.gov.br/anuario 2010/index.html (2012)

Os estabelecimentos agrícolas, por sua vez, estão categorizados conforme a Figura 8.

Figura 8: Paranapanema III Quantidade de Estabelecimentos por tamanho

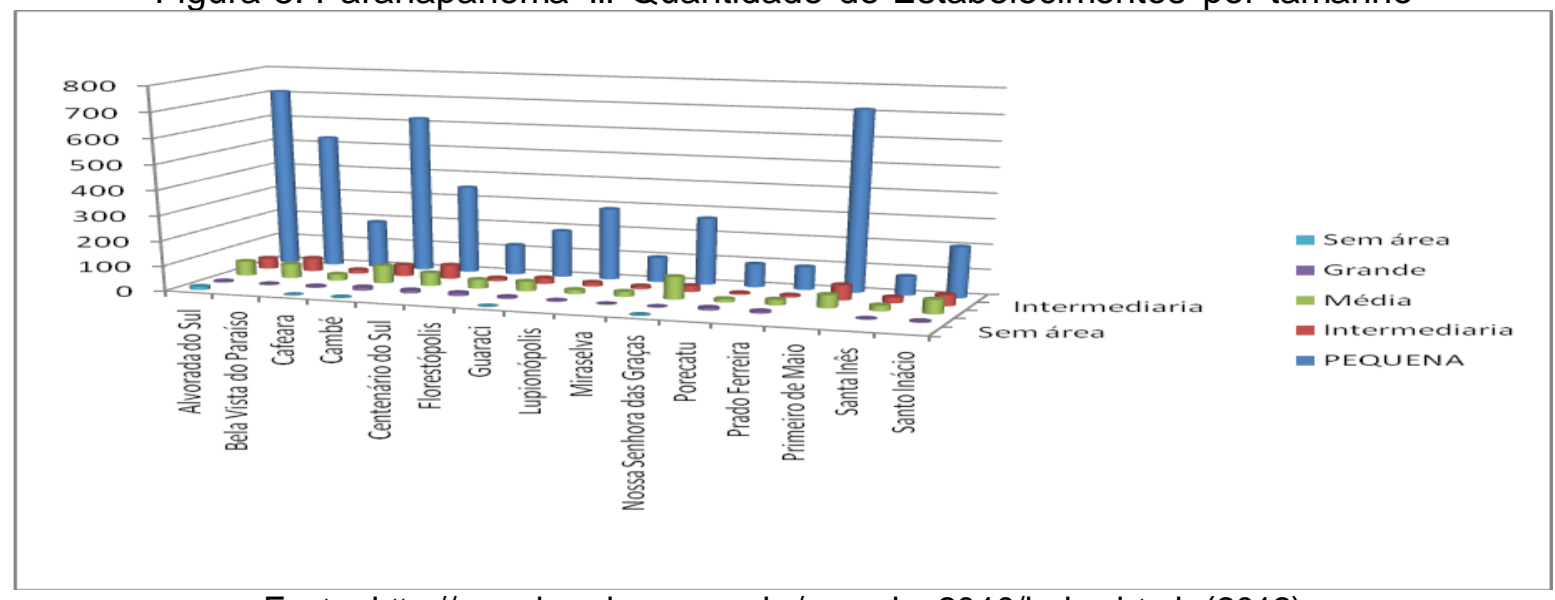

Fonte: http://www.ipardes.pr.gov.br/anuario 2010/index.html (2012)

$\mathrm{Na}$ bacia existem 5.715 estabelecimentos, os quais se enquadram em grande parte, em micro a pequenos estabelecimentos (79,4\%, ou 4.537 dos 5.715 estabelecimentos existentes) na bacia. Destacam-se os municípios de Primeiro de Maio (715 dos 827 que elas possui são pequenos), Bela Vista do Paraiso (712 dos 831 estabelecimentos). Na bacia existem 15 municípios dos quais 5 possuem os sem área, que somam 20 estabecimentos, sendo os de Alvorada do Sul (13 est.) e Cambé (3), os com maior quantidade. 
Na Bacia de Paranapanema III, as maiores áreas ocupadas por proprietários são nos municípios de Centenário do Sul (41.888ha dos 43.948 ha total, que correspondem a 420 estabelecimentos.) e Cambé (41.729ha dos 48.182 ha e 548 estabelecimentos). Contudo a maior quantidade de estabelecimentos proprietários é em Primeiro de Maio (653 estabelecimentos.) e Alvorada do Sul (712 estabelecimentos que correspondem a 22.981 ha), portanto, a área média bem menor.

Figura 9: Estabelecimentos Rurais na Bacia Paranapanema III

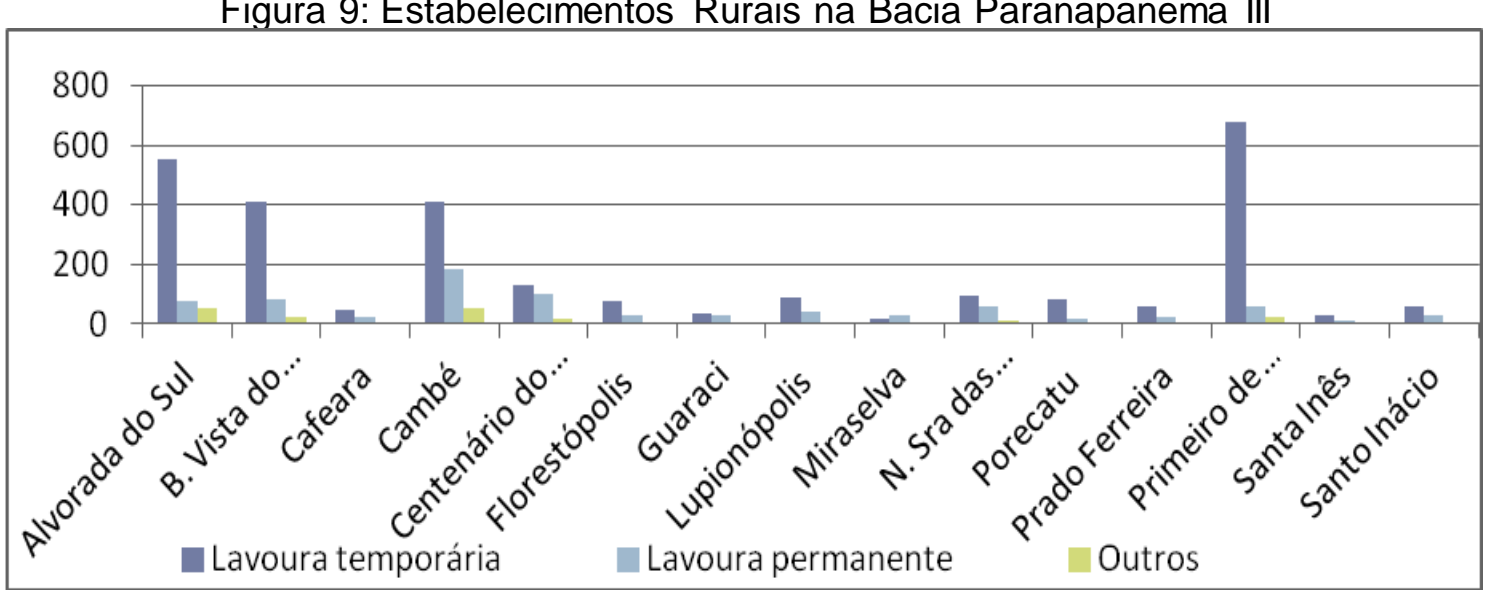

Fonte: http://www.ipardes.pr.gov.br/anuario 2010/index.html (2012)

O município que apresenta maior número de sem área é o de Alvorada do Sul com 13 dos 20 estabelecimentos de sem área existentes. As atividades existentes nos estabelecimentos são apresentados nas Figura 9 e 10

$\mathrm{Na}$ Bacia do Paranapanema III as Lavouras Temporárias se encontram em 2.750 estabelecimentos, que ocupam uma área de 229.229 ha. $(83,35$ ha em media por estabelecimento). As Lavouras Permanentes estão em 792 propriedades e ocupam uma área de 61.075 ha $(77,14$ ha em média), ou seja, as lavouras temporárias ocupam uma área média cerca de $8 \%$ maior do que a permanente.

$\mathrm{Na}$ atividade outras se encontram as sementes, florestas, horticultura, floricultura. Os Municípios que se destacam em número de estabelecimentos com lavouras temporárias são os de Alvorada do Sul (551 propriedades com 22.993 ha) dedicada a soja e milho, Cambé (408 estabelecimentos com 37.439 ha) soja e trigo, Centenário do Sul se destaca nas lavouras permanentes (9.968 ha em 101 estabelecimentos) com soja e Cambé (182 estabelecimentos 6.953ha.) com café.

A Figura 10 apresenta os produtos mais significativos em termos de área ocupada na bacia. O $1^{\circ}$ lugar com Cana de Açúcar (maior produção), no qual se sobressaem Porecatu com área de 
9.455 ha., que produziu 772.823 toneladas, seguido por Santo Inácio (9.750 ha.) que produziu 729.970 toneladas e Centenário do Sul (8.533 ha.) e 707.300 toneladas. A Soja ocupa o 2o lugar e tem a maior área plantada em Cambé (32.000 ha.) com 102.400 toneladas, seguido por Primeiro de Maio (21.887 ha.) com 68.287 toneladas e Alvorada do Sul (19.650 ha.) com 61.308 toneladas.

Figura 10:As Culturas mais significativas em área plantada da Bacia Paranapanema III

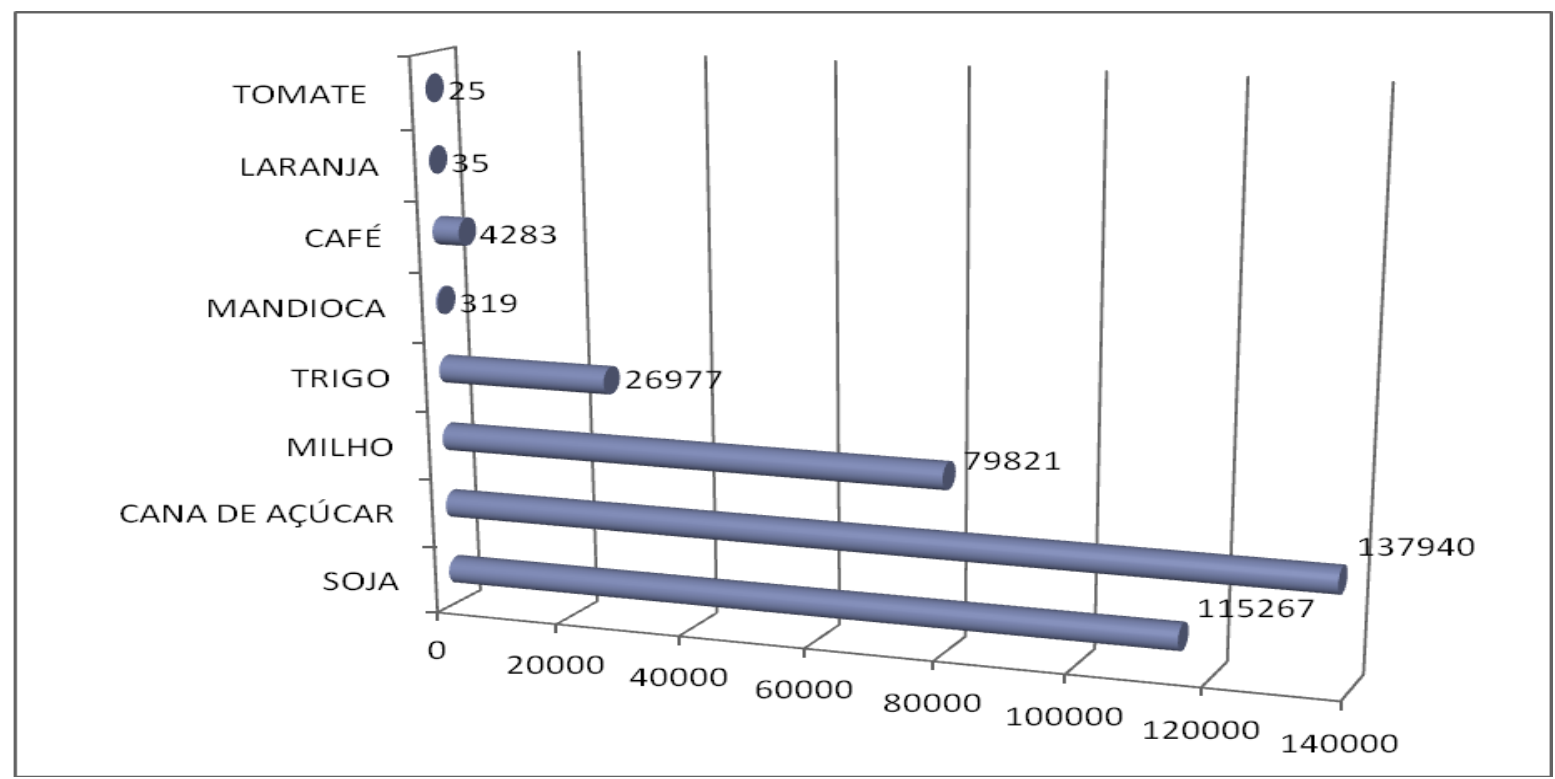

Fonte: http://www.ipardes.pr.gov.br/anuario 2010/index.html (2012)

\subsubsection{A Bacia do Rio Paranapanema IV}

A Bacia do Paranapanema IV gerou em 2010, o valor de $R \$ 561.118,35$ mil. O PIB per capita da bacia foi de $R \$ 10.305,55$, variando de $R \$ 6.987,13$ em Diamante do Norte a $R \$$ 14.441,80 em Jardim Olinda. Apesar do Jardim Olinda ter o maior PIB per capita, o município com a maior geração de valor, medido pelo seu PIB foi o de Paranavaí com $\mathrm{R} \$ 924.553,00$ e PIB per capita de $\mathrm{R} \$ 11.177,44$, por concentrar grande população. Os maiores PIBs, após Paranavaí, se localizam em Nova Esperança, Loanda e Terra Rica, todos se destacando perante os demais municípios, na geração dos três setores, conforme figura 11. 
Figura 11: PIB Por Categoria Econômica dos Municípios do Paranapanema IV, 2010

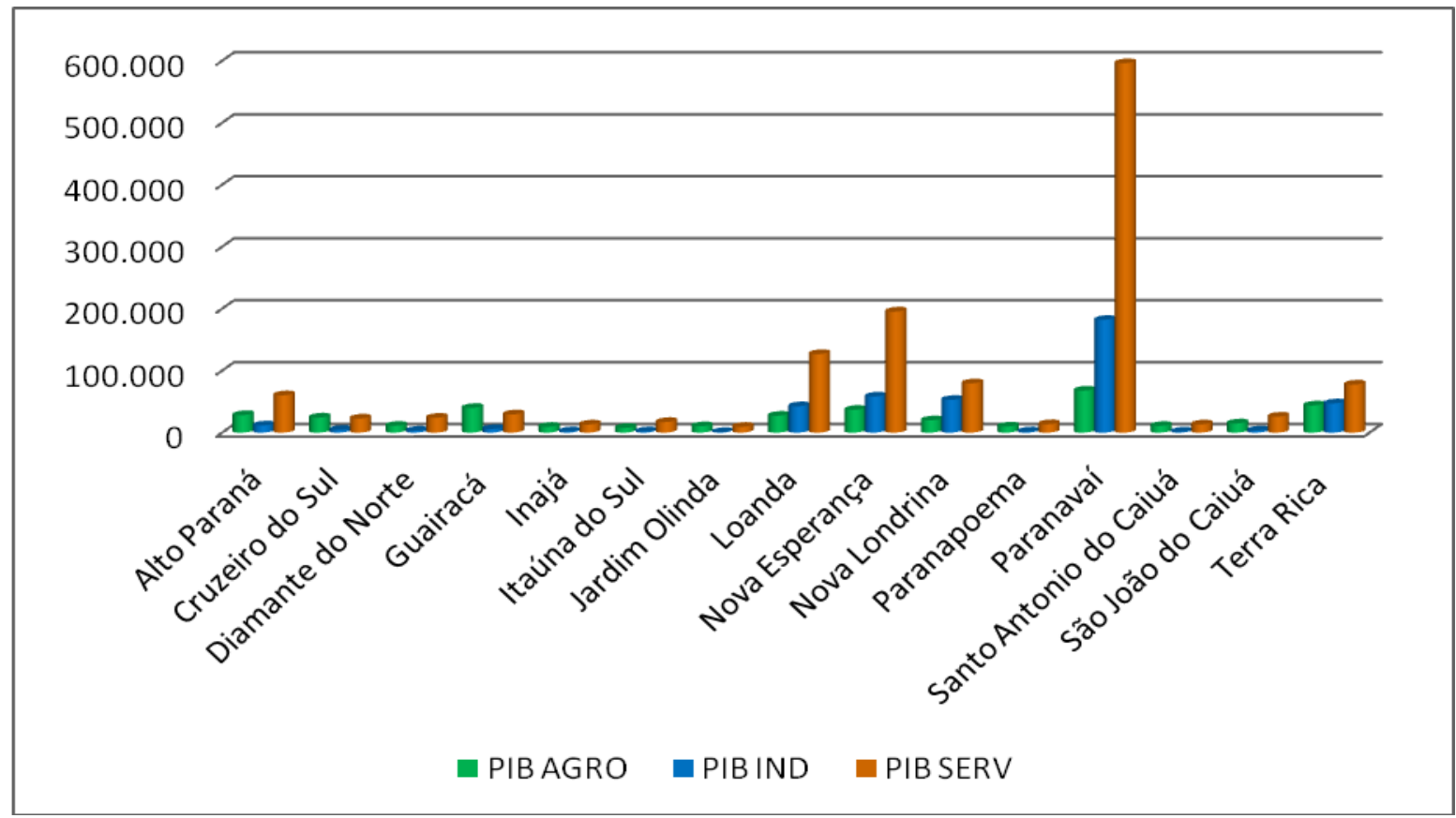

Fonte: http://www.ipardes.pr.gov.br/anuario 2010/index.html (2012)

No agropecuário existem 7.258 estabelecimentos que totalizam 556.915ha. em todos os municípios predominam os proprietários em número e área, conforme mostra a Figura 21 e 22. A Bacia possui 6.030 proprietários ocupando uma área de 479.519 ha e 394 arrendatários com 18.521 ha. Destas, Paranavaí possui 1.264 proprietários, que ocupam área de 107.731 ha e 101 arrendatários com área de 4.864 ha. Alto do Paraná possui 720 proprietários em área de 47.802 ha e Nova Esperança com 701 proprietários ocupando área de 23.443 ha.

Chama a atenção os assentados sem título que se destacam em Paranavaí (245 estabelecimentos, ou seja, 12.575 ha dos 125.443 ha total, 10,0\%) e Terra Rica com 200 estabelecimentos (14.373ha de 83.786ha total, ou seja, 17,2\%). Os sem área estão também em Terra Rica e representam 15 estabelecimentos dos 20 existentes na bacia (75\%) apontando para problemas que existem em Terra Rica. 
Figura 12 - Quantidade de estabelecimentos por tamanho

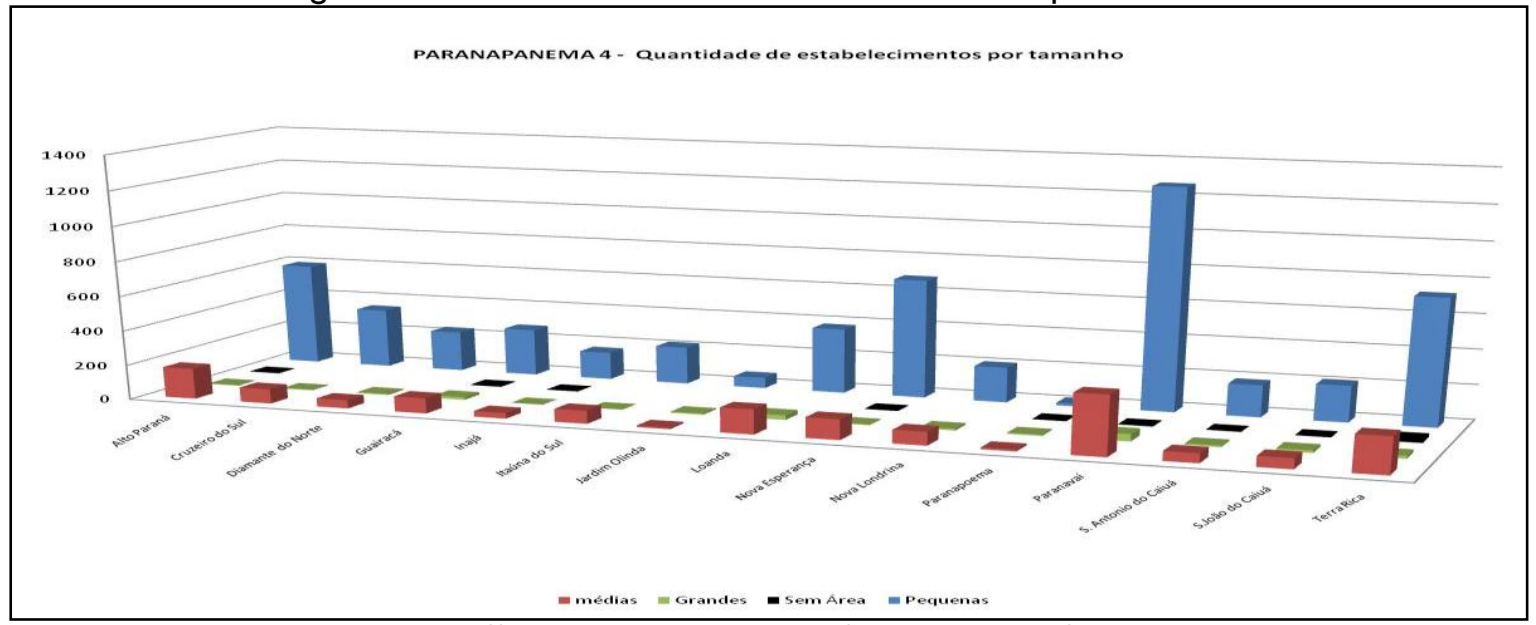

Fonte: http://www.ipardes.pr.gov.br/anuario 2010/index.html

Dos 7.258 estabelecimentos da bacia, se classificam como pequenos (até 50 ha) 5.540 estabelecimentos $(76,3 \%$ do total); 1.13 como de tamanho médio $(20,8 \%)$ e ainda se encontram 36 sem área. Com relação às atividades desenvolvidas, as Figura 13 mostra as mesmas.

O Paranapanema IV possui 1.448 propriedades com Lavouras Temporárias e área de 140.655ha. Paranavaí se destaca nas lavouras temporárias, pois, possui 443 propriedades rurais (30,6\% do total da bacia), com lavouras temporárias em 32.360 ha (23,0\% da bacia). O segundo Município a se destacar é Alto do Paraná com 164 (11,3\% do total da bacia) propriedades com Lavouras Temporárias e área de 11.071ha. (7,8\% da bacia).

Figura 13 - Paranapanema 4 - lavouras desenvolvidas - 2010

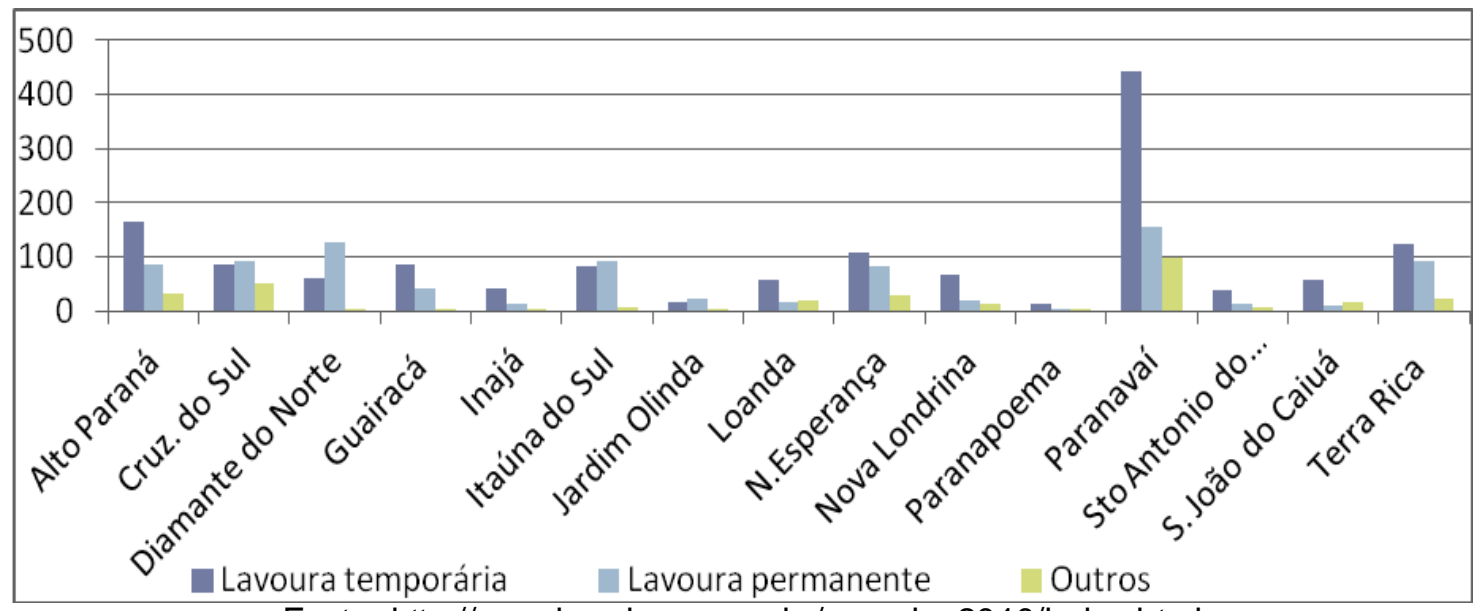

Fonte: http://www.ipardes.pr.gov.br/anuario 2010/index.html 
As Lavouras Permanentes estão presentes em 869 propriedades e 89.915 ha. Nesta bacia destaca-se, novamente, Paranavaí que possui 157 estabelecimentos (18,1\% da bacia0 com 23.868ha.(26,5\% da bacia) Ainda se destaca Diamante do Norte com 128 propriedades e 2.823 ha de lavoura permanentes.

Figura:14:As Culturas mais significativas em área plantada da Bacia Paranapanema IV

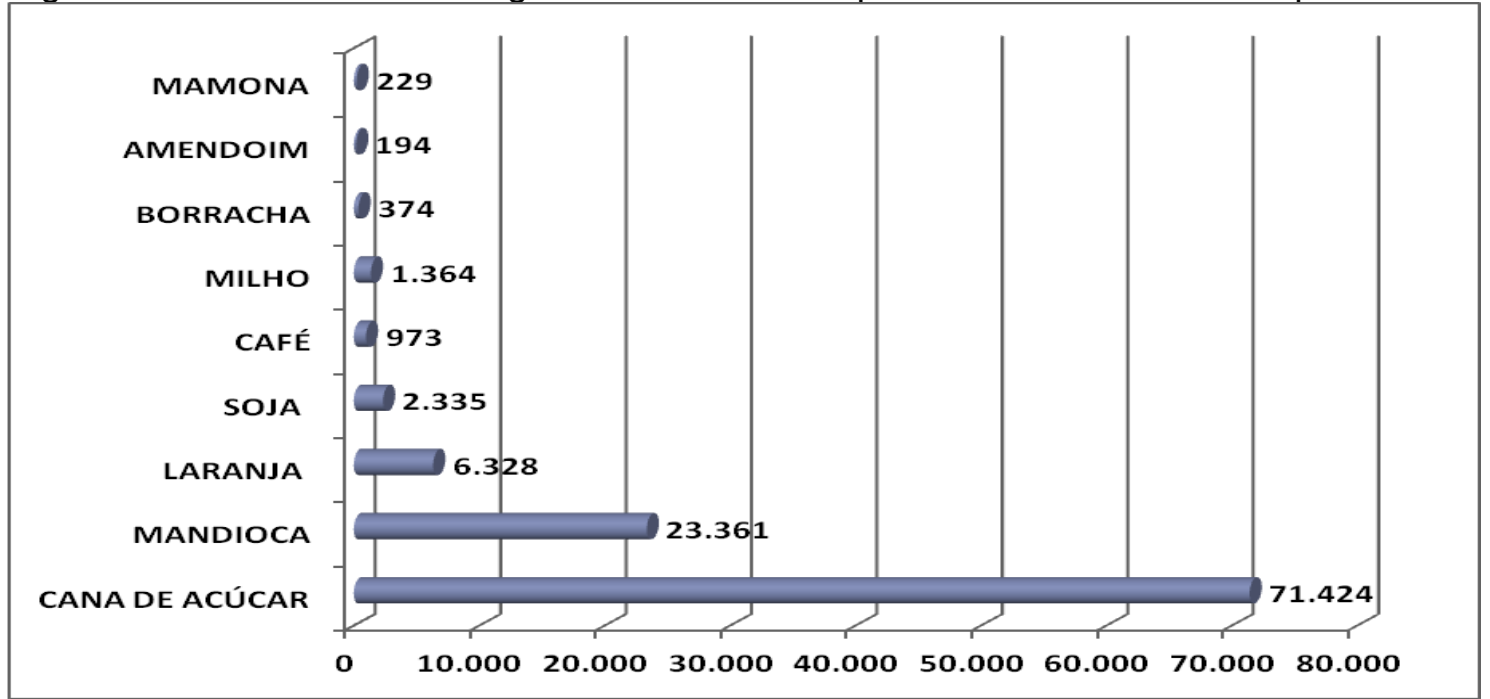

Fonte: http://www.ipardes.pr.gov.br/anuario 2010/index.html

A Figura 14 apresenta os produtos mais significativos em termos de produção. O 1ำ lugar com Cana de Açúcar se localiza em Cruzeiro do Sul, que possui uma área de 8.189 ha e produziu 622541 toneladas, seguida por Guairaçá (9.057 ha.) produziu 618.617 toneladas e Inajá (5.419 ha.) e produziu 411.766 toneladas.

A Mandioca ocupa o 20 lugar tem a maior área plantada em Alto do Paraná (3.000 ha.) com 78.518 toneladas e Terra Rica (2.820 ha.) 73.320 toneladas produzidas e Santo Inácio do Caiuá (1.431 ha.) com 33.810 toneladas.

\subsubsection{A Bacia do Pirapó}

A Bacia do Pirapó gera a maior riqueza relativamente as outras duas bacias. Na bacia o PIB per capita varia de $R \$ 29.903,81$, em Lobato a $R \$ 6.698,00$, de Sarandi. 
Figura 15: PIB por Categoria Econômica dos Municípios do Bacia do Pirapó, 2010

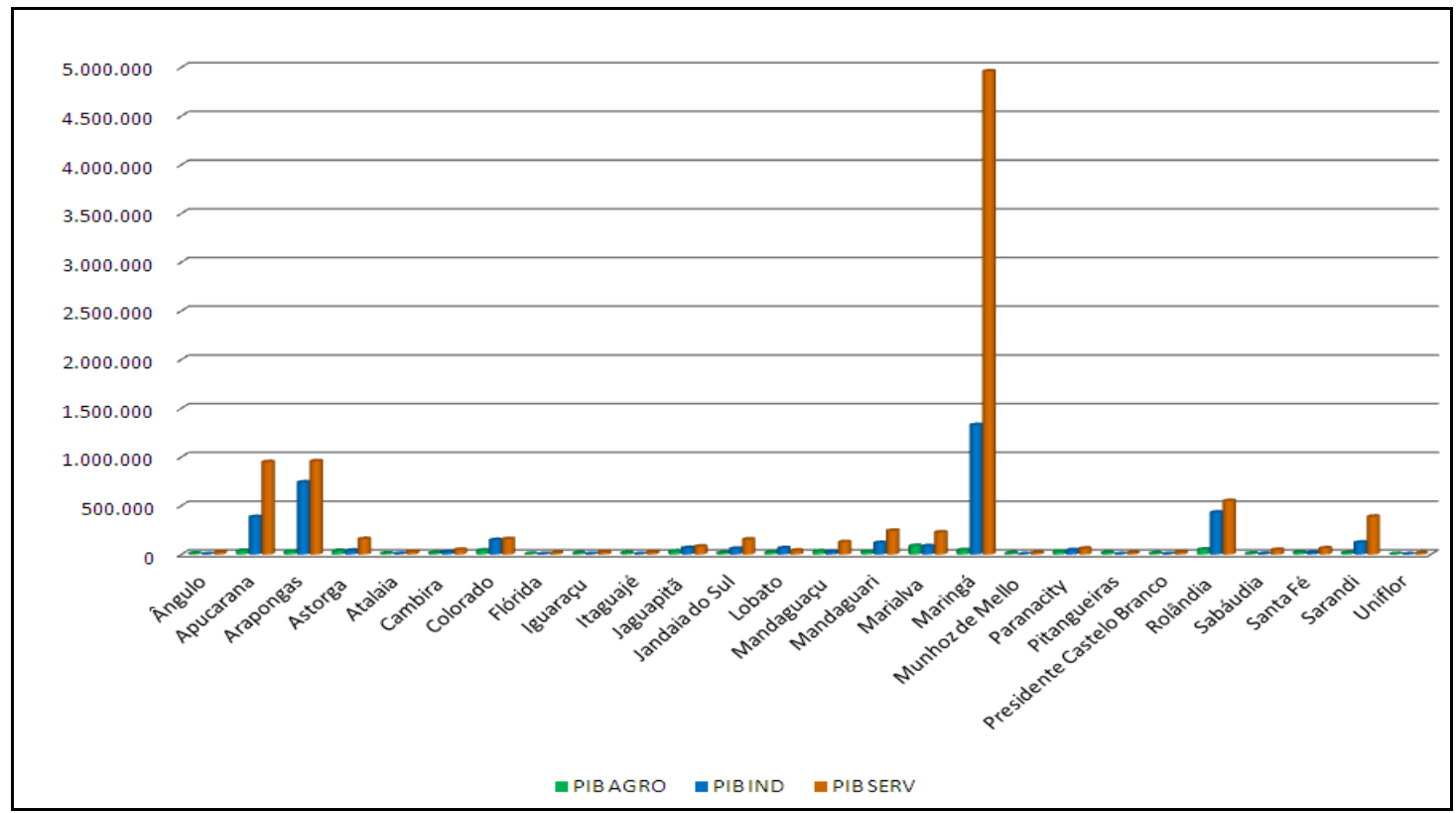

Fonte: http://www.ipardes.pr.gov.br/anuario 2010/index.htm

Maringá tem o maior PIB $\mathrm{R} \$ 7.284 .401,00 \mathrm{mi}$ e se destaca tanto no de origem serviços quanto industrial. Destacam-se ainda Arapongas, Apucarana e Rolandia nas duas áreas. Quanto a Agricultura Marialva se destaca como se pode verificar na figura 15.

Existem 15.176 estabelecimentos que ocupam uma área de 926.978ha, destes, 12.693 estabelecimentos (83,6\%) e 645.265ha (69,6\%) estão nas mãos dos proprietários, que prepondera em todos os municípios da bacia.

O município de Marialva tem a maior quantidade de proprietários, ou seja, 1.405 estabelecimentos dos 1.658 estabelecimentos do município (84,7\% dos estabelecimentos do município), que ocupam uma área de 35.883 ha dos 39.948 ha do município $(89,8 \%)$. Segue Apucarana, que possui 1.368 proprietários de um total de 1.834 estabelecimentos no município (74,6\%) e área de 42.153 ha. de um total de 50.173ha. (84,0\%). Com relação aos arrendatários, que são em número de 1507 e ocupam uma área de 59.928ha. destaca-se em área o município de Presidente Castelo Branco com 17 estabelecimentos (1,1\%) que ocupa área de 12.665ha (21,1\%), portanto, altamente concentrado. Quanto ao tamanho dos estabelecimentos, tem-se a Figura 16. 


\section{Fom \\ anctere \\ Fórum Ambiental \\ da Alta Paulista

Figura 16 - Estabelecimento por tamanho na Bacia do Pirapó

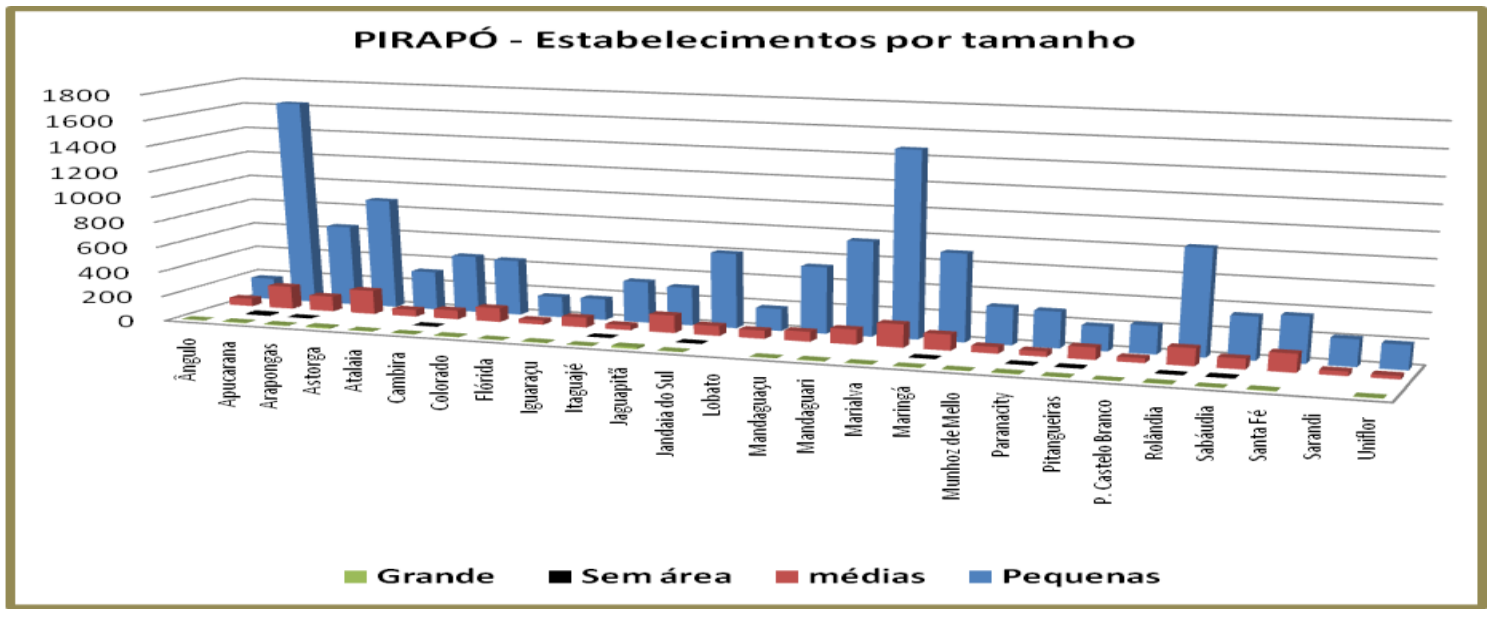

http://www.ipardes.pr.gov.br/anuario 2010/index.html

Pela mesma, pode-se dizer que Apucarana (com 1.636 estabelecimentos), Marialva (1.471 est.) e Rolândia (835 est.) concentram, juntos, 31,1\% dos pequenos estabelecimentos (que somam 12.659 estabelecimentos).

Os médios estabelecimentos somam 2.395 estabelecimentos e Marialva (183 est.), Astorga (191 est.) e Apucarana (183 est.) possuem 23,3\% dos mesmos. Quanto aos grandes estabelecimentos, estes somam 93 em toda a bacia, sendo que Astorga (com 10 est.) e Jaguapitã (com 15 est.) concentram 26,9\% dos mesmos. Os sem area são em número de 28 e estão concentrados em Apucarana (10 est.) e Sabaudia (15 est) que juntas representam 65\% dos mesmos. Com relação às atividades desenvolvidas apresentam-se as figuras 17.

Figura 17 - Pirapó - Estabelecimentos com culturas.

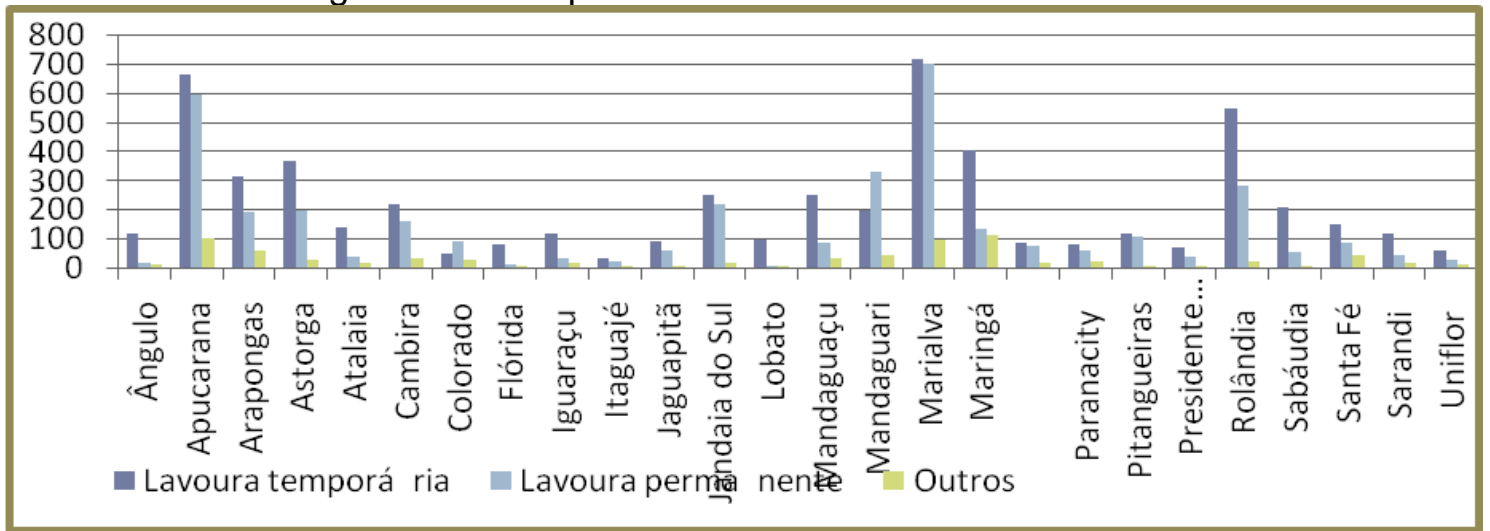

http://www.ipardes.pr.gov.br/anuario 2010/index.html 


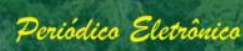 \\ ISSN 1980-0827

As Lavouras Temporárias, na Bacia do Pirapó, ocupam uma área de 533.460 ha distribuídas por 5.574 propriedades e Lavouras Permanentes, com 177.953 ha que se encontram em 3.714 propriedades. Nesta, Marialva possui 718 propriedades com Lavouras Temporárias e 28.197 ha e 701 propriedades com Lavouras Permanentes e 6.131 ha. além disso, destaca-se Apucarana com 664 propriedades com Lavouras Temporárias e 22.726 ha e 596 propriedades com Lavouras Permanentes e 12.276 ha. Ainda ha Rolandia, que possui 548 estabelecimentos com Lavouras Temporárias e 27.621 ha e Mandaguaçu, com Lavouras Temporárias em 329 estabelecimentos que somam 5.327

A Figura 18 apresenta os produtos mais significativos em termos de área e de produção. 0 1ำ lugar, com Soja (maior produção) está com Arapongas, que possui uma área de 19.200 ha com a cultura e produziu 53.760 toneladas, seguida por Apucarana (18.500 ha), que produziu 53.650 toneladas e Astorga (17.100 ha), com 51.300 toneladas.

Figura: 18: As Culturas mais significativas em área plantada da Bacia do Pirapó

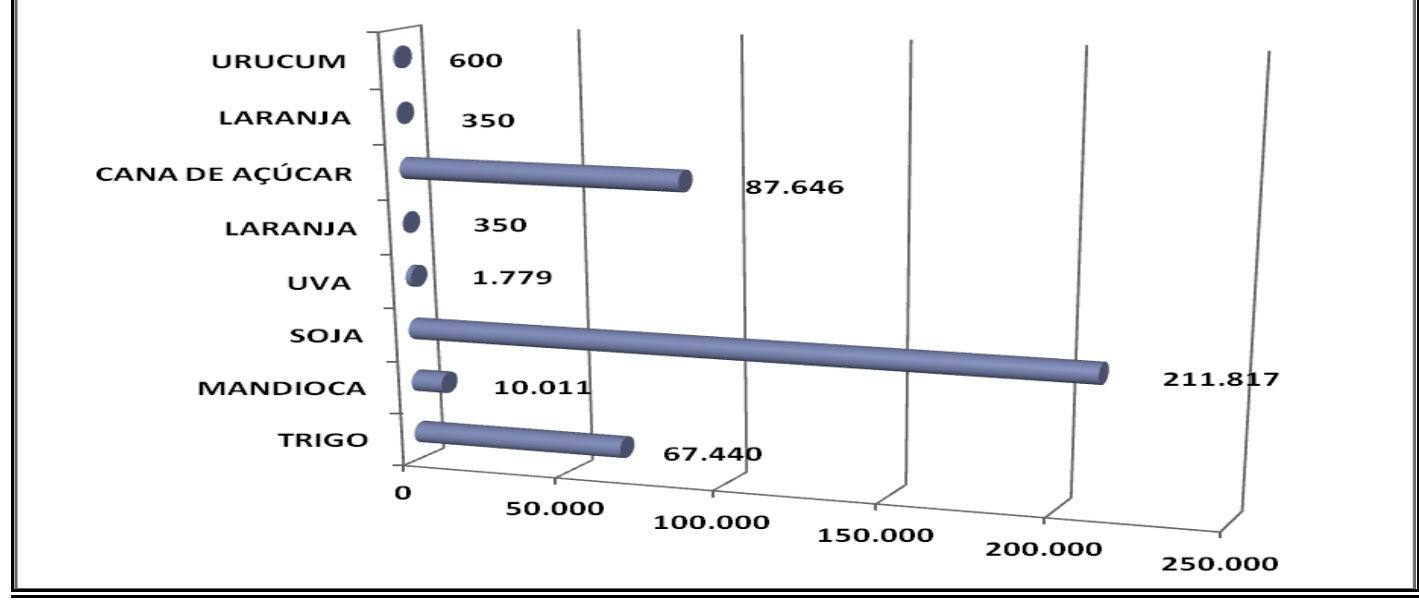

Fonte: http://www.ipardes.pr.gov.br/anuario 2010/index.html

A Cana de Açúcar ocupa o 2ํㅣㅁ lugar e tem a maior área plantada em Colorado (15.056 ha), com 1.175.680 toneladas produzidas, seguido por Jaguapitã (8.404 ha), com 678.623 toneladas e Lobato (6.820 ha), com 557.262 toneladas.

\section{CONSIDERAÇÕES FINAIS}

Nas Bacias o desenvolvimento a capacidade de articulação no uso e ocupação do solo, é analisado por meio dos aspectos econômicos, especificamente a agricultura, pôde-se verificar 
algumas características regionais que são peculiares como a base produtiva, atividades agropecuária. Pode-se considerar que um plano de ação para a Bacia Hidrográfica que pode obedecer algumas características em comum para todos os municípios visando o desenvolvimento da região. Quanto a atividades agrícolas projetos verifica-se o crescimento da produção tanto de lavoura permanente como temporária, bem como os setores alimentícios.

Os objetivos de uma política de desenvolvimento para a região das Bacias seriam o de atribuir ao tecido econômico regional para um desenvolvimento autônomo.preservando as Bacias, através de política em parcerias com os atores do setor público, privado e comunidade em geral em busca da elevação do estado de bem-estar humano e ambiental.

\section{REFERÊNCIAS}

AIYAR, S. S.; PIRIOU-SALL, S.; MCLEAN, K.; WILLIAMS, M. The political economy of democratic decentralization. Washington, DC: World Bank-Agricultural \& Natural Resources Department, 1996.

ALMEIDA, J. R. de (coord.). Planejamento Ambiental. Caminho para participação popular e gestão ambiental para o nosso futuro comum. Uma necessidade, um desafio. Rio de Janeiro: Thex Editora, 1993.

ALMEIDA, M. H. T. de. Federalismo e políticas sociais. In: AFFONSO, R.; BARROS

SILVA, P. L., org. Federalismo no Brasil: descentralização e políticas sociais. Atlas: São Paulo, 1996

CLEMENTE, Ademir. HIGACHI, Hermes Y. Economia e desenvolvimento regional. - São Paulo : Atlas, 2000.

CMMAD - COMISSÃO MUNDIAL SOBRE O MEIO AMBIENTE E O DESENVOLVIMENTO -. Relatório Nosso Futuro Comum. $2^{a}$ ed. Rio de Janeiro: Editora da Fundação Getulio Vargas, 1991, p.46,47.

FARIA, Antonio. Programa oportunidades de mercado e apoio à agricultura familiar: Hulha Negra/RS. In FRANÇA, Cássio Luiz de. VAZ, José Carlos. SILVA, Ivan Prado. (org) Aspectos econômicos de experiências em desenvolvimento local. Instituto Polis : São Paulo, 2002.

ESPINOSA, H.R.M. Desenvolvimento e meio ambiente sob nova ótica. Ambiente, Vol. 7, n. 1,1993.

FIRJAN. Índice Firjan De Desenvolvimento Municipal $\quad($ IFDM)<Disponível em http://www.firjan.org.br/IFDM/>Acesso em Jun 2012.

IBGE CIDADES Disponível em <http://www.ibge.gov.br/cidadesat/topwindow.htm?1> Acesso em Jun 2012. 
IDHM. Ìndice De Desenvolvimento Humano - Municípal, 1991 E 2000 Disponível em<http://www.pnud.org.br/atlas/ranking/IDHM\%2091\%2000\%20Ranking\%20decrescente\%20\%28 pelos\%20dados\%20de\%202000\%29.htm > Acesso em Jun 2012.

IPARDES.

Cadernos

Municipais $<$ Disponível

em http://www.ipardes.pr.gov.br/index.php?pg_conteudo=1\&cod_conteudo=30>Acesso em Jun de 2012.

SIDRA.IBGE.Tabela787. Número de estabelecimentos e área dos estabelecimentos agropecuários, por condição legal do produtor em relação às terras, sexo do produtor, grupos de atividade econômica e grupos de área total (vide nota de rodapé) Disponível em <http://www.sidra.ibge.gov.br/bda/tabela/listabl.asp?z=t\&c=787>Acesso em Jun de 2012. 